\title{
An Arendtian Reading of Eugene Ionesco's Rhinoceros and Liwaa Yazji's Goats through the Notions of Totalitarianism and The Banality of Evil
}

\author{
Asst. Prof. Hany Ali Mahmoud Abdelfattah \\ Department of English, Faculty of Alsun, Minia University
}

\begin{abstract}
This paper is a comparative literary study of two absurd plays: Eugene Ionesco's Rhinoceros (1959) and Liwaa Yazji's Goats (2018). It traces their points of overlap with and departure from the tenets of the Theatre of the Absurd; illustrates the theoretical framework of Hannah Arendt's notions, as introduced in The Origins of Totalitarianism (1951) and Eichmann in Jerusalem: A Report on the Banality of Evil (1963); and attempts to answer these questions: How does Totalitarianism use propaganda, terror, and religion to brainwash the minds of the Romanians and Syrian? How does Arendt's banality of evil explain conformity and loyalty? Both playwrights employ elements of distanciation: Ionesco uses metatheatre and Yazji uses videos, screens, camera gaze, crowds, and six goats on the stage to incite spectators to think and break the illusion. The paper also entails a recognition of 'animality' and offers to conceptualize this term vis à vis totalitarianism and the Theatre of the Absurd.
\end{abstract}

Keywords: Totalitarianism, Arendt, Rhinoceros, Goats, the banality of evil. 
مجلة وادي النيل للاراسات والبحوث الإنسانية والاجتماعية والتربوية (مجلة علمية محكمة)

(ISSN : 2536 - 9555)

قِرَاءَة آرنتيه ليوجين يونسكو خرتيت ولِوَوَاءٌ يازجي مـاعز مِنْ خِلَلِِ مفهومي

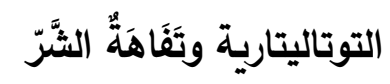

أ.م.د. هانى على محمودعبدالفتاح

قسم اللغة الإنجليزية، كلية الآلسن، جامعة المنيا

الْخُلَاصَة

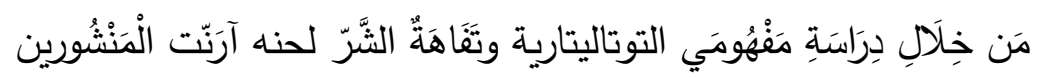

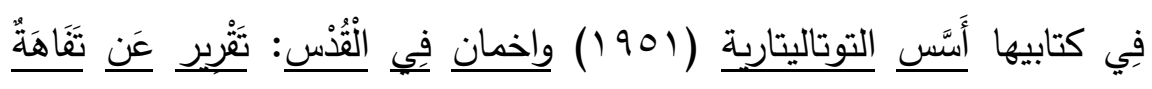

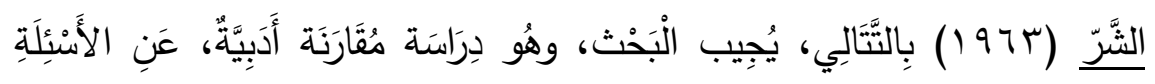

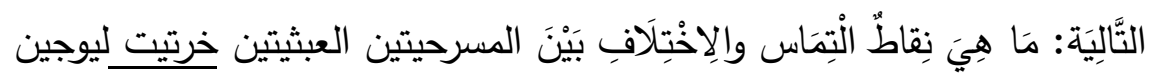

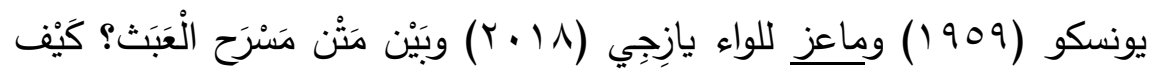

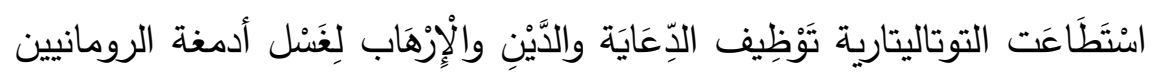

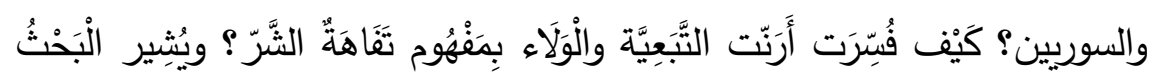

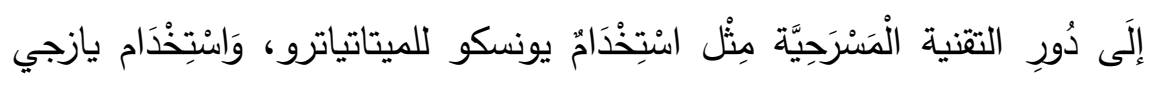

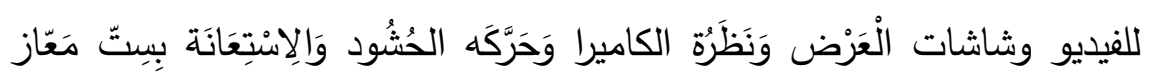

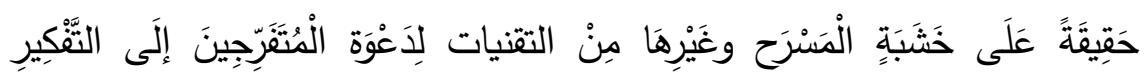

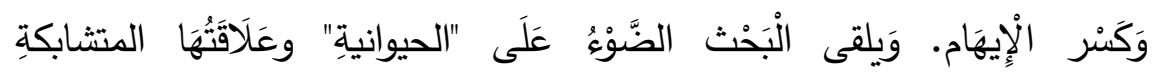

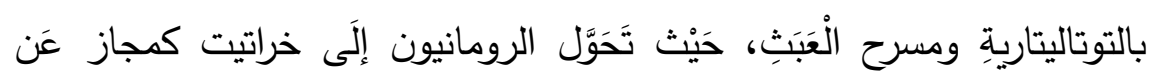

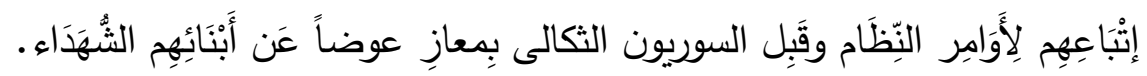

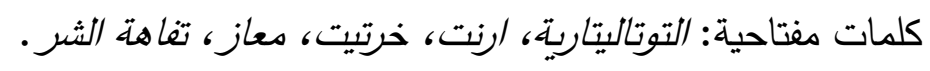


An Arendtian Reading of Eugene Ionesco's Rhinoceros and Liwaa Yazji's Goats

through the Notions of Totalitarianism and The Banality of Evil

Asst. Prof. Hany Ali Mahmoud Abdelfattah

مجلة وادي التيل للاراسات والبحوث الإنساتية والاجتماعية والتربوية (مجلة علمية محكمة)

\section{Introduction}

Eugene Ionesco's Rhinoceros and Liwaa Yazji's Goats present the grim reality of totalitarianism in both Romania and Syria. After the horrible atrocities of World War II, Ionesco wrote Rhinoceros in 1959 to draw an absurd picture of the Romanians' metamorphosis into a horned herd as a metaphor for their conformity with the strange demands of the Fascists. ${ }^{1}$ After almost sixty years, Liwaa Yazji staged her play Goats in 2018 in London as an absurd representation of a real event where goats were distributed to Syrians in compensation for their martyred sons. In the two plays, the theatre of the absurd exposes the ills of totalitarianism which muted free voices, persecuted educated people, and discouraged society's organizations.

\section{Methodology and Objectives}

Drawing on Hannah Arendt's The Origins of Totalitarianism (1951) and Eichmann in Jerusalem: A Report on the Banality of Evil (1963), the paper investigates how Fascism and Ba'athism are brainwashing people. I argue that Romanians and Syrians, associated with these Fascist or Ba'athist regimes, are just executors of orders and unable to question or oppose things. Points of convergence and divergence between the two plays and the principles of the theatre of the Absurd are explored. Furthermore, the presence of animals on stage and the interrelationship between animality, totalitarianism, and absurdity will be investigated.

\section{The Theoretical Framework}

At the beginning of the twentieth century, totalitarianism had emerged as a ruling system that requires "(1)a totalist (sic) ideology, (2) a single party committed to this ideology and usually led by one man, the dictator" (1969, p. 126) as Carl J. Friedrich asserted. Totalitarian rulers are assumed to be "endowed with supernatural, superhuman, or at least specific exceptional powers or qualities" (Weber, 1947, p.358). In the Arab World, Totalitarianism followed the same route; it emerged in the form of 
(ISSN : 2536 - 9555)

youth movements that quickly developed into fully-fledged political parties such as the Arab Socialist Ba'ath Party in Syria and Iraq which "came to power in Syria in 1963, was inspired mainly by the works of its founder Michel Aflaq" (Tomass, 2016, p.163). The word 'Ba ath,' which means in Arabic "resurrection," aimed to restore the former glory of the Arabs through achieving sovereignty and promoting economic unity. ${ }^{2}$ Under the umbrella of the totalitarian parties, people were amenable to being absorbed into a single party and controlled by a dictator, who suppressed them.

In The Origins of Totalitarianism, Arendt expounds on how the totalitarian state is formed. ${ }^{3}$ She starts by differentiating between three categories: the tribe, the mob, and the masses. The tribe is the primitive form of the state, the mob is its core, and the masses are its power. The totalitarian state is a "state in appearance only" (Origins, 1973, p.266). It is controlled by the mob which is "a group in which the residue of all classes are (sic) represented" (Origins, 1973, p.225). It incites violence which surprisingly for the mob's leaders looks "like harmless child's play" (Origins 108). ${ }^{4}$ Since propaganda relied on the charisma of the leader and his oratory skills, Hitler, who was "a mass orator" (Origins, 1973, p.361), won the hearts of millions of Germans. Terror is the other side of the coin; it is "the very essence of its form of government" (Origins, 1973, p.344) and it is intended to subjugate the masses psychologically. Religion is discarded as heresy by the socialists, but Nazis and Ba'athist are keen on exploiting the concept of martyrdom to brainwash the masses and thus recruiting them into the army.

In Eichmann in Jerusalem: A Report on the Banality of Evil (1963), Arendt launched her controversial term "the banality of evil," claiming that Adolf Eichmann, a Nazi senior lieutenant colonel who was responsible for the deportation of thousands of Jews to Auschwitz, was just an executor of orders and not guilty of war crimes. Arendt, who was selected due to her painful experience with the Nazi concentration camps to be The New Yorker's reporter in Israel for Eichmann's trial, surprised everyone 
An Arendtian Reading of Eugene Ionesco's Rhinoceros and Liwaa Yazji's Goats

through the Notions of Totalitarianism and The Banality of Evil

Asst. Prof. Hany Ali Mahmoud Abdelfattah

مجلة وادي النيل للاراسات والبحوث الإنسانية والاجتماعية والتربوية (مجلة علمية محكمة)

with her report, in which she claimed that Eichmann "was not one of the ruling cliques, he was a victim, and only the leaders deserved punishment" (Eichmann, 1964, p. 247).

\section{Eugene Ionesco and Liwaa Yazji}

Eugene Ionesco and Liwaa Yazji are worlds apart. However, their careers, traumas, persecution, education, and views run parallel to each other. Both are diasporic, highly educated, and preoccupied with the devastating consequences of the wars that tore apart their countries. They resisted the status of subordination of all aspects of life to the authority of the state through oppression and they mourn pluralism, diversity, and individualism that had been diminished in favor of conformity and acquiescence to the regime.

Ionesco was a Romanian-born French who spent his formative years in the 1930s where the Iron Guard, a burgeoning Fascist movement, was raging among the youths. He studied French literature at the University of Bucharest and became a French teacher, then he found his niche in writing for the theatre. He opposed all forms of ideologies, outward religious conformity, and herd mentality.

Yazji was born in Moscow in 1977 because her mother, a gynecologist, and her father, an artist, were on a scholarship to Russia. In the 1980s, Yazji's family returned to Syria and Yazji studied English literature at Damascus University. After the Arab Spring in 2011, she moved to England and there she unleashed her pent-up anger and criticism of the Ba'ath Party. In 2014, she released her first film Haunted in France. In 2016, her play Goats was staged at the Royal Court Theatre in London, achieving tremendous success. ${ }^{5}$

\section{Review of the Literature}

There are a plethora of reviews on Ionesco's Rhinoceros (1959) in comparison to just a few of Yazji's Goats (2018). In 
(ISSN : 2536 - 9555)

books, Ionesco's theatre is still a fertile ground for many scholars. In his introduction to the book Reassessing the Theatre of the Absurd (2011), Michael Bennet recommends reading Rhinoceros with the conviction that Camus was not an existentialist. There are a few books on the Syrian plays: one of them is Edward Ziter's Political Performance in Syria: Studies in International Performance in 2015. It traces the Syrian theatre before and after the Civil War in 2011, examining a myriad of directors and themes. He divides the book into five chapters where he discusses the works of Naila al-Atrash, the concept of martyrdom, the impact of the Palestinian diaspora on the Syrians, and the torture in the Syrian theatre.

In articles, many have focused on the autobiographical elements in Rhinoceros such as M. Calinescu (1995); AH Quinney (2007); and WS Haney (2008). Other articles by P. Fambrough (2010) and F. Jahangiri (2016) have explored the association between Rhinoceros and the Menippean and Marxist philosophies. The articles on Goats are mostly interviews and reviews that took place in Britain, as Charlotte Bailey (2016); Emma GrahamHarrison (2017); and Aleks Sirez (2018). Sarah Youssef's “Arab Dramaturgies on the European Stage: Liwaa Yazji's Goats and Mohammad Al Attar's The Factory" is a thorough comparative study between two Syrian plays, focusing on traumas, economy, and the documentary materials.

In academic dissertations, scholars have started to discuss the general themes of Ionesco's dramatic technique, absurdity, and victimization, and as in Coakley (1967); Kelly (1977); and Deverson (1978). Others have pinpointed the overlapping between Ionesco and Brecht as in Wulbern (1967) who sees that Brecht's vision of the theatre is influenced by communism. Others have investigated the common ground between Ionesco and the Jarresque drama as in Luciano (1978) or with the Japanese playwright Kobo Abe in Yasaka (1979).

Kathleen Clare Kemock's dissertation titled "The Rhinoceros in 2006: A Dramaturgical Analysis of Eugène 
An Arendtian Reading of Eugene Ionesco's Rhinoceros and Liwaa Yazji's Goats through the Notions of Totalitarianism and The Banality of Evil

Asst. Prof. Hany Ali Mahmoud Abdelfattah

مجلة وادي التيل للاراسات والبحوث الإنسانية والاجتماعية والتربوية (مجلة علمية محكمة)

Ionesco's "Rhinoceros" explores how technology resists conformity and herd mentality. In Egypt, Engy El-Sayed Bahnas's "The Influence of Ionesco on Egyptian Dramatists with a Special Reference to Tawfik Al-Hakim, Salah Abdel-Sabour, and Naguib Sorour" (2018) explores how Ionesco's influence, after the bitter defeat of Egypt in the Six-Day War in 1967, becomes evident on Tawfik Al-Hakim's Tree Climber, Abdel Sabour's Night Traveller, and Naguib Sorour's Crosswords.

Based on the review of the literature, there is no scholarship on the study of Ionesco's Rhinoceros and Yazji's Goats from the perspectives of totalitarianism and the banality of evil. It also charts new grounds in investigating the presence of animals on the stage, offering to associate it with totalitarianism.

\section{A Comparative Critical Analysis of Rhinoceros and Goats}

\section{The Plot}

The plot of the Rhinoceros is circular: it starts and ends at the same point. The first and the last image of the stage show Berenger alone. In an unknown town, Berenger, an alcoholic young employee, meets his co-worker Jean, who is sober and neat. Jean blames Berenger for his bad habits and aimlessness. Papillon, Daisy, Botard, Dudard, Boeuf, Jean, and Berenger work in an office where they proofread law proposals. From time to time, a rhinoceros runs across the streets, causing great terror and agitation. As rhinoceros besiege the building, Berenger escapes and visits Jean and watches his metamorphosis in terror. Daisy, whom Berenger is madly in love with, finds rhinoceroses appealing and leaves him. Berenger, outnumbered by the townspeople, declares "I will not capitulate!"

The plot in Goats is linear-structured: Abu Firas refuses to bury his son, heckles the ceremony, finds out the truth, and is killed. The story unfolds with a huge ceremony in the small Syrian town at the time of the civil war. Abu Firas never stops questioning the conditions of his son's murder despite the several attempts by 
(ISSN : 2536 - 9555)

Abu al-Tayyib, the head of the party, to soothe him. He strikes a deal with Abu al-Tayyib and comes out on live TV and apologizes. After seeing the mutilated corpse of his son, he starts to look for the truth. He finds out that the regime orders the soldiers to call their families back home whenever they besiege terrorists. The regime locates their places and bombards the soldiers and the terrorists. Abu Firas incites Imm Ghassan, Adnan, and Zahra to revolt. He becomes unbearable for the regime. Finally, he is found dead with a suicide note in his pocket.

\section{The Tools of Totalitarianism}

\section{Propaganda}

Propaganda machines of the totalitarian regimes usually hold big ceremonies, in pompous TV production, with representatives of the party, journalists, and villagers to make announcements, celebrate the martyrs, or distribute donations. Propagandists are also keen on keeping the national collective memory of the people entangled with a "Calendrical liturgy" (Connerton, 1989, p. 41) to celebrate the national days in the history of the nation and transform the fiascoes into victories. Therefore, Joseph Gobbles, the Nazi Minister of Propaganda, kept a yearlong calendar, which starts on 30 January with the anniversary of Hitler's ascent to power. On 24 February, Germany celebrated the foundation of the National Socialist Party (Connerton, 1989, p. 42). Bouthaina Shaaban, the Syrian Propaganda Minister, mimics Gobbles' style of commemorating the national holidays by keeping a calendar all year long for the ceremonies to commemorate the fallen soldiers to both Turkish and Israeli occupiers. On May 6, the Syrian nation "celebrates the 1916 Ottoman execution of the nationalist leaders" (Ziter, 2014, p.118). On 6 October, the Syrian nation celebrated the 1973 War against Israel. These celebratory ceremonies link the past and the present, making these anniversaries a fully unified history of the nation.

Ba'ath party has followed suit, Yazji describes how the Ba'ath party celebrates the nation's martyrs: 
An Arendtian Reading of Eugene Ionesco's Rhinoceros and Liwaa Yazji's Goats through the Notions of Totalitarianism and The Banality of Evil

Asst. Prof. Hany Ali Mahmoud Abdelfattah

مجلة وادي النيل للاراسات والبحوث الإنسانية والاجتماعية والتربوية (مجلة علمية محكمة)

The first coffins are fully draped in clean flags with bright colours, and some with banquets and wreaths...The sound of ululating fills the space as the WOMEN enter, weeping and wearing black, in a funeral tradition that is reminiscent of a wedding. (Goats, 2018, p. 6)

Ba'ath party transforms the scene from mourning to celebration, from weeping to ululating, and from grief to pride. Families of the martyrs are being congratulated and thanked for the martyrdom of their sons. Everything is prepared in advance to welcome the coffins of the martyrs: cameramen are kept on standby, guards watch over the crowds, speeches and even interviews are scripted and reviewed. Nevertheless, in a hilarious scene, Imm Nabil, a mother of a martyr, is scolded by the TV presenter for not reading from a script "Why aren't you saying anything? The answers are right here!" (Goats, 2018, p. 53), she remains silent. Later, the villagers murmur into the TV anchor's ear that Imm Nabil is blind!

Ordinary people are easily convinced by the propaganda, but highly educated people with a "methodical mind," are not (Rhinoceros, 1960, p. 41). Botard, a former teacher, does not believe the testimonies of his co-workers and says:

BOTARD. I never believe journalists. They're all liars. I don't need them to tell me what to think; I believe what I see with my own eyes. Speaking as a former teacher, I like things to be precise, scientifically valid; I've got a methodical mind. (Rhinoceros, 1960, p. 41)

Abu Firas is also a teacher: he is a history teacher who is descended from a patriotic family, as his father "was a coffinbearer for our late president" (Goats, 2018, p. 10), as Abu Samer contends. One of his lessons is titled "Independence Revolts against the Ottoman Empire" (Goats, 2018, p. 41) in which he attempts to associate the uprising against the Ottoman rule with the revolution against Bashar regime. He believes that history repeats itself in various forms and by different means. ${ }^{6}$ In so doing, Abu 
(ISSN : 2536 - 9555)

Firas bets on the consciousness of the people like Zahra, Imm Ghassan, Adnan, and others to form a united front against the totalitarian $\mathrm{Ba}$ athist regime.

\section{Terror}

For Arendt, a totalitarian regime depends on terror to subjugate the masses. ${ }^{7}$ Stalin spread terror by instigating a "permanent purge," and the Nazis struck terror into the hearts of the people by making everyone live in fear of finding out a Jewish grandfather in the family tree (Saxonberg, 2019, p.16). In Rhinoceros, terror is spread through the actors' imaginary transformation into rhinoceroses. Jean, the lifelong friend of Berenger, is transformed into a rhinoceros and in a terrorizing manner.

JEAN: [from the bathroom] I'll trample you; I'll trample you down! [A lot of noise comes from the bathroom, trumpeting, objects falling, the sound of a shattered mirror; then BERENGER reappears, very frightened) (Rhinoceros, 1960, p. 69)

Berenger observes how the physical shape of Jean changes: his skin turns green; he "is getting longer and longer" (Rhinoceros, 1960, p. 69), and his voice becomes hoarse. In Goats, terror is apparent in the hilarious but frightening metamorphosis of Adnan, a soldier in the National Syrian Army, who returns from the war to find that "There are more goats than there are men" (Goats, 2018, p. 51). Sarcastically, Adnan acts as if he is a goat and he starts to bleat in shrieking voices, guzzle food, and roam around. This has struck terror in his wife and mother's hearts who kept watching him in awe.

(ADNAN gets down, then gets on all fours and approaches the goat. IMM GHASSAN cries). ADNAN. "why are you crying? Is he (the goat) cute? Don't we look nice together? (Bleating like a goat.) Is that good, or is my voice too low? Why isn't it answering me? I want a blue ribbon for my 
An Arendtian Reading of Eugene Ionesco's Rhinoceros and Liwaa Yazji's Goats

through the Notions of Totalitarianism and The Banality of Evil

Asst. Prof. Hany Ali Mahmoud Abdelfattah

مجلة وادي النيل للاراسات والبحوث الإنسانية والاجتماعية والتربوية (مجلة علمية محكمة)

neck. When I turn into a goat will we be able to talk to each other? (Goats, 2018, p. 98)

The moments of metamorphosis are different between the plays: Berenger is watching in great terror how everyone becomes a real rhinoceros, whereas Adnan is mocking what goats do to his townspeople, cutting the telephone cords, knocking everything in their routes, and causing a huge commotion and disturbance.

Terror has been used in many different techniques with $\mathrm{Abu}$ Firas to contain his rebellious and incessant inquiry about his son's corpse, which is regarded by the regime as "contagion" (Goats, 2018 , p. 29). First, they attempt to "make him come back to the fold" (Goats, 2018, p. 31). Second, they attempt to threaten him by sacking him from his job as a teacher, as Abu Al-Tayyib confirms, "I don't want to be disrespectful. But you make it, well-unavoidable. Abu Firas, it is time we let you take a break" (Goats, 2018, p. 41). After seeing the mutilated corpse of his son, Abu Firas is now certain that his son had been left to the stray dogs to eat his corpse.

\section{Religion}

Religion has been used by totalitarian regimes to amass the young people to fight for the state and to die honorably. Hitler calls the people who made the coup with him "martyrs" to grant them the honor of being the defenders of the state. ${ }^{8}$ However, in Rhinoceros, Botard despises religion and calls it "collective psychosis" (Rhinoceros, 1960, p. 40) whose followers are "just idlers with nothing to do" and still believe in superstitions such as "flying saucers" (Rhinoceros 42). He even declares that he deliberately works "on Sundays" (Rhinoceros, 1960, p. 40) in contempt of the Christian religion.

In Goats, martyrdom has turned to be an absurd form of livelihood. Families of the martyred sons have been rewarded with goats in compensation for the death of their sons. Martyrdom is emphasized by the sheikhs who propagate the ideology of the 
مجلة وادي النيل للاراسات والبحوث الإنسانية والاجتماعية والتربوية (مجلة علمية محكمة)

(ISSN : 2536 - 9555)

regime, convincing the masses that the regime is doing what is religiously right. When theocrats fail to fulfill their duties, they are reprimanded by the autocrats for not doing their jobs, as when Abu al-Tayyib blames the sheikh for being hesitant about Abu Firas's right to see the corpse of his son.

ABU AL-TAYYIB. And I still will not let you speak... The martyr belongs to his nation! What does that mean, Sheikh? A soldier doesn't sacrifice himself for Mummy and Daddy and the living room! The Holy Quran and the Hadith declare a martyr must be buried where he falls--and not lie around waiting for a visit from his family. (Goats, 2018, p. 32)

Propagandists depend on the image of the martyrs as the magnet which attracts the youth to be recruited in the army to fight the terrorists. ${ }^{9}$ In sectarian war-torn Syria, propagandists, on both parts, exploited the high rank of the martyr in both Shiite and Sunni sects of Islam to lure the youths to enlist in the army to fight each other, propagating that their murdered sons are the true martyrs who will go to the Jannah and will be rewarded.

\section{The Banality of Evil}

In the twentieth century, people had to work more than they used to do in the previous centuries due to the high demand for food supplies, international competition, and world wars. Totalitarianism has exploited this need by creating blind spots in people's minds where they disregard moral judgment as a dereliction of duty and look at work with solemnity and unquestionable obedience. It also abused the workers in the name of productivity and crushed their moral conscience. Consequently, they become obedient creatures who lack the will to question or oppose the orders which come from their superiors. In Rhinoceros, work has been metamorphosed into a solemn 'duty,' as Jean asserts:

JEAN. The superior man is the man who fulfils his duty.

BERENGER. What duty?

JEAN. His duty ... His duty as an employee, for example. 
An Arendtian Reading of Eugene Ionesco's Rhinoceros and Liwaa Yazji's Goats through the Notions of Totalitarianism and The Banality of Evil

Asst. Prof. Hany Ali Mahmoud Abdelfattah

مجلة وادي التيل للاراسات والبحوث الإنساتية والاجتماعية والتربوية (مجلة علمية محكمة)

(Rhinoceros, 1960, p. 7)

Jean openly boasts of his long working hours, as when he says, "I spend eight hours a day in an office...And I only get three weeks off a year" (Rhinoceros, 1960, p. 7). He admonishes Berenger for his laziness "Isn't it better to be fresh and eager, even at work?" (Rhinoceros, 1960, p. 22). Berenger, who cannot keep abreast of his friend's activities, declares, "I'm not made for the work" (Rhinoceros, 1960, p. 8). Mr. Papillon, the boss of the employees at the organization, is an epitome of a bureaucrat who is always demanding more and more effort to be exerted in "the working hours" (Rhinoceros, 1960, p. 44). He interrupts the hot discussion about the rhinoceros and yells, "Gentlemen I think it is high time we started to work" (Rhinoceros, 1960, p. 44). After rumors and gossip spread that there are rhinoceroses in town, he hushes his employees and yells "You're not paid to waste your time arguing about real or imaginary animals" (Rhinoceros, 1960, p. 45) and declares "Work must go on!" and "We are in working hours" (Rhinoceros, 1960, p. 45). When rhinoceroses besieged Berenger and Daisy, Berenger yells, "Stop it! You're preventing us from working!" (Rhinoceros 101). Work has to go on no matter what happens and man's obsession with work will lead definitely to a sense of self-satisfaction. Even when a fire breaks out and firefighters are evacuating employees from their offices, he wants "you all back in the office this afternoon" (Rhinoceros, 1960, p. 45). He stresses the importance of work regardless of what is going on in the town as when he orders his secretary Miss Daisy to come and type the letters at his house and asks Berenger to show up at the office, asserting that "we are not on holiday, and that work will resume as soon as possible" (Rhinoceros, 1960, p. 55). When Papillon notices that $\mathrm{Mr}$. Boeuf is going to be a rhinoceros before his own eyes, he asserts "Well! That's the last straw. This time he's fired for good!” (Rhinoceros, 1960, p. 50).

The employees in Rhinoceros are all like Eichmann: they are doing their job without questioning the consequences of their 
(ISSN : 2536 - 9555)

actions. Their administrative work is a solemn "duty" and when they do it, they become "superior" men, as Botard confirms (Rhinoceros, 1960, p. 7). They swore on oath to be loyal to their employers and co-workers, "I feel certain scruples! I feel it's my duty to stick by my employers and my friends, through thick and thin" (Rhinoceros, 1960, p. 93), as Dudard declares.

Obedience is not an option; it is an honor. Before the court in Jerusalem, Eichmann declared "My Honor is my loyalty" (Eichmann, 1964, p. 135). In Goats, loyalty to the party, and thence to the state is an honor and a sacred duty, especially at the time when the state proclaims that it is fighting terrorism. Hence. everyone must obey the orders "which come from above" (Goats, 2018, p. 25), e.g., Abu Ramez, one of the party's henchmen, cuts "his thumb to vote with his blood" (Goats, 2018, p. 25). In another instance, Abu Al-Tayyib admonishes a comrade because his wife, who is supposed to be nominated for election, got pregnant, as he says, "Abu Salma, you can postpone a pregnancy, you can't postpone an election. (Goats, 2018, p. 25). In this atmosphere, Abu Firas's inquiry is regarded as political dissent; unless it is suppressed, it will escalate into a full-scale rebellion.

\section{Technique}

Rhinoceros and Goats differ in the way they followed the principles of the theatre of the absurd. Rhinoceros is a typical absurd play in which time and place are unknown, action is static, language turns to be mere cliches, and characters are grotesque. It focuses on the plight of the man who feels like an alien in a "universe suddenly divested of illusions and lights" (Camus, 1955, p. 6). Berenger, like all the absurd protagonists, is confronted with a "bewildering experience, a veritable barrage of wildly irrational, often nonsensical goings-on that seems to go counter to all accepted standards of stage convention" (Esslin, 1960, p. 4). It breaks all the conventional standards of the traditional theatre whether they are action, language, characterization, and technique.

Action contributes nothing to the development of the events: Berenger remains alone until the end of the play and his character 
An Arendtian Reading of Eugene Ionesco's Rhinoceros and Liwaa Yazji's Goats

through the Notions of Totalitarianism and The Banality of Evil

Asst. Prof. Hany Ali Mahmoud Abdelfattah

مجلة وادي النيل للاراسات والبحوث الإنسانية والاجتماعية والتربوية (مجلة علمية محكمة)

does not develop or have a dramatic change. Language is mere cliches and repetitions, as it is evident in the senseless debate between the logician and the old gentleman about syllogism:

LOGICIAN. [to the OLD GENTLEMAN] Here is an example of a syllogism. The cat has four paws. Isidore and Fricot both have four paws. Therefore, Isidore and Fricot are cats. (Rhinoceros, 1960, p. 18)

The logician, who can prove anything through logic, is a grotesque character. He distracts the audience with his claims of the types of rhinoceros and their horns, completely ignoring the dangers of stampeding rhinoceros breaking out into the town. Thus, he is just like the intellectuals who play down the rise of totalitarianism in their communities and are only concerned with trivial matters.

Another grotesque character is Jean who always blames Berenger for being lazy and alcoholic, as when he advises him, "Instead of squandering all your spare money on drink, isn't it better to buy a ticket for an interesting play?" (Rhinoceros, 1960, p. 23). But when Berenger asks Jean to go with him to a theatre, Jean, surprisingly, apologizes and says, "I have to meet some friends for a drink" (Rhinoceros, 1960, p. 24). Jean's answer is in direct contradiction to what he always proclaims of being sober and active. Apparently, the intended perlocutionary effect that Jean intends to achieve, which is to encourage Berenger to quit drinking and watch a play, is hindered by Jean himself. Berenger's flaw is his belief that an uttered speech means exactly what it says. Therefore, language becomes just a purveyor of sounds and cliches rather than a vehicle for meaning.

On the other hand, Goats is different; it is a burgeoning form of the theatre of the absurd. Time and the place are known and identified: time is the aftermath of the Syrian Civil War in 2013 and the place is a small Syrian town. Action is dynamic: it is rising when Abu Firas interrupts the ceremony, reaches the climax when he sees the mutilated body of his son, and comes to a 
(ISSN : 2536 - 9555)

denouement when Abu Firas is killed. Language is full of cliches, repetitions, and irony. There is one sentence that is repeated over and over by the Sheikh which is "You're quite right" and he says it to both Abu Firas and Abu al-Tayyib whenever they want him to approve their points of view. The two opponents also attempt to use language in their favor: Abu Al-Tayyib uses religious and patriotic terms such as "martyrdom," "Holy Qur'an," "Hadith," and "terrorists" throughout to grant legitimacy to the ongoing war against terrorists and glorify loyalty to the state and the party. Abu al-Tayyib also warns his fellow villagers that Abu Firas's refusal of the burial of his son will "desecrate the sanctity of the coffins" (Goats, 2018, p.13), and that bears a great affinity to the action of Creon in Sophocles' Antigone when he orders not to bury the corpse of Polyneices. Abu al-Tayyip exploits this religious taboo and attempts to make the conflict between Abu Firas and religion, not with the government, accusing him of blasphemy. On the other hand, Abu Firas uses words such as 'cannon fodder,' 'our children,' 'stolen', and a barrage of nominative and possessive plural pronouns such as 'we' and 'our' to make his fellow villagers collectively responsible for the killing of their sons.

The use of the foils abounds in the two plays: Berenger and Jean; Dudard and Botard; Imm Ghassan and Abu Firas; and Zahra and Adnan. Berenger is lethargic, downtrodden, and alcoholic, whereas Jean is active, optimistic, and healthy. Dudard is a positivist who believes in what he sees, whereas Botard is a socialist and atheist. Abu Firas is outspoken and stubborn, whereas Imm Ghassan is mute and surrendering. Zahra is ambitious and patriotic, while Adnan is defeated and traitorous.

Both playwrights use a myriad of anti-theatrical techniques to break the illusion and the identification and halt the process of catharsis. In Rhinoceros, Ionesco uses the metatheatrical technique to refer to himself, as when Jean asks Berenger to go out to watch a play by Ionesco:

JEAN. [to BERENGER] Instead of squandering all your spare money on drink, isn't it better to buy a ticket for an 
An Arendtian Reading of Eugene Ionesco's Rhinoceros and Liwaa Yazji's Goats

through the Notions of Totalitarianism and The Banality of Evil

Asst. Prof. Hany Ali Mahmoud Abdelfattah

مجلة وادي النيل للاراسات والبحوث الإنسانية والاجتماعية والتربوية (مجلة علمية محكمة)

interesting play? Do you know anything about the avantgarde theatre there's so much talk about? Have you seen Ionesco's plays? (Rhinoceros, 1960, p. 23)

By writing about himself, Ionesco proves to be selfconscious. The audience will notice that at once and realize that they are watching a play. In so doing, Ionesco breaks the illusion of the theatre, calling the audience to think, not to catharize.

Noises are used menacingly in the two plays: in Rhinoceros, noises of the trampling of the rhinoceros are getting louder and louder in each act. Jean utters noises when he is transformed into a rhinoceros in the bathroom. In Goats, the sounds of the gunshots are getting higher throughout to show how closely the civil war is, as Yazji indicates in her notes, "The sounds of fighting, missiles and explosions gradually become clearer and clearer over the course of the play" (Goats, 2018, p. 5). Noise has also been used in a new way, e.g., "ululating," which is a high-pitched sound that is always accompanied by the motion of the uvula, is not only used for mourning the death of someone and also for celebration. Rather, it is used to "cover up the sounds of Abu Firas's yelling to stop the ceremony" (Goats, 2018, p. 15). Thus, it becomes a suppressing tool, hindering the voices of Abu Firas whenever he attempts to heckle the celebration.

Rhinoceros followed the principles of the theatre of the absurd and used a nihilistic strategy which is difficult "to draw any conclusions about the world view or philosophical implications of the text or acting" (Pavis, 1998, p. 2). Meanwhile, Goats deviates from following the principles of the theatre of the absurd and identifies time and place. Thus, it uses a satirical strategy in which it gives "a fairly realistic account of the represented world" (Pavis, 1989, p. 2).

Both playwrights wrote stage directions: Yazji wrote 'Note on Play" while Ionesco left introductions and descriptions in each act. Stage directions are essential to the directors: they function as 
(ISSN : 2536 - 9555)

metatext that informs them along with the actors of how the playwright envisions the performance, without imposing restrictions on them.

In her "Note on Play," Yazji writes that she uses "videos prepared in advance, and archival material" (5) which are Brechtian anti-theatrical techniques that aim to present facts about the real bombardment, killing, and displacement of thousands of Syrians. Upon entering the theatre, the audiences see "a live recording from the stage" ("Note on Play" 5) done by a cameraman and a reporter. This live reporting creates a dichotomy between two worlds: the world of reality and the world of illusion, exposing how lies become truths.

Yazji uses actors who "were or currently are personally affected by the civil war" (Youssef, 2017, p. 2) and this allows actors to infuse parts of their personal experiences into the show without fully narrating what happened to them.

In her notes, Yazji writes that "the cameraman affects the gathered villagers' behavior" (Goats 5). It is evident that crowd behavior is affected by the motion of the camera: the camera acts as the gaze of the onlooker which is "a part of the overall functioning of power" Foucault, 2007, p. 174). In Discipline and Punish: The Birth of the Prison, Foucault introduces the gaze as a means of surveillance and control, asserting that the gazer is superior to the object of the gaze, as he notes, "It is the normalizing gaze, a surveillance that makes it possible to qualify, to classify and to punish. It establishes over individuals a visibility through which one differentiates them and judges them" (Foucault, 2007, p. 184). Therefore, the mere presence of the camera, whether it is switched on or off, will stifle individuality and reinforce conformity in the crowd. No one dares to stand out of the crowd or behave badly for fear of being caught or punished by the Ba'athist members.

Yazji also recommends that the audience "may be treated as villagers" (Goats, 2018, p. 5). These villagers are the crowd that moves as an entity in one direction. Freud explains that in a crowd, 
مجلة وادي النيل للاراسات والبحوث الإنسانية والاجتماعية والتربوية (مجلة علمية محكمة)

the feeling is infectious, as he confirms "In a crowd, every sentiment and act is contagious, and contagious to such a degree that an individual readily sacrifices his personal interest" (1955, p. 21). On stage, the crowd represents the masses who are susceptible to persuasion by image, emotion, and rhetoric. At the same time, the crowd is "antithetical to reason, dialogue, and individuality" (Jannarone, 2009, p. 193). Therefore, individuality dissolves and conformity prevails, as what happens when Abu Firas interrupts the ceremony, the crowd moves on "towards Abu Firas and attempt to calm him with pleasantries" (Goats, 2018, p. 10).

\section{Animals}

Animals have existed on the stage since Greek theatre. Aristophanes' The Frogs (405 BC) was a play about a chorus of frogs. Thereafter, animals appeared in many plays around the world. In William Shakespeare's theatre, animals are used to express aspects of human identity, as Greta Olson finds that "Richard III compared extensively to animals like dogs, boars, toads, and spiders in order to cast him as a verminous criminal (2003, p. 301). Animals also appear physically on the Shakespearian stage as "a naughty dog in The Two Gentlemen of Verona and a hungry bear in The Winter's Tale" (Raber, 2015, p. 290). It is also evident that Shakespeare rarely used the word 'animal" but he "uses the term beast 141 times and creature 127 times" (Spevack, 1970, p. 179).

Animals in Rhinoceros and Goats open a new venue to discuss how the totalitarian regimes dealt with animals--a topic that is worthy of a separate study. Totalitarian regimes are known for exploiting animals in wars. In World War II, Nazis used millions of horses in their wars against the Russians in Siberia. It was estimated that the Germans in just two months of December 1941 and January 1942 had lost " 179,000 horses" on the eastern front. (Dunn, 1995, p. 19). In the Syrian civil war, the Ba' ath regime used goats to compensate the families of the martyrs. 
(ISSN : 2536 - 9555)

In both plays, animals have been used as zoomorphic tropes of human behavior. A rhinoceros is a huge, short-sighted, wild animal which makes it a metaphor for a conformist in a totalitarian regime. A goat is a small, boisterous, and domestic animal that is bred for its meat and milk. A goat is pliant but noisy, and that makes it easy prey for wolves. Goats are distributed to the families of the martyrs as a means of compensation, but, at the same time, they are metaphors of how the young Syrians have become sacrificial animals for the regime.

The moral standard is what differentiates humans from animals, as Berenger asserts "Well, at any rate, we have our own moral standards which I consider incompatible with the standards of these animals" (Rhinoceros, 1960, p. 91). When humans breach this moral standard, they become animals or a "pachyderm" as when Daisy describes the sexual advances of her boss Mr. Papillon, who attempts to touch her. She yells, "You keep your horny hands off my face, you old pachyderm!" (Rhinoceros, 1960, p. 50).

\section{Conclusion}

The resonances between Romania 1930 and Syria 2013 are striking. Fascist and Ba'athist parties used the long arms of totalitarianism such as propaganda, terror, and religion to transform their people into mere cogs in the wheels of the regimes. Propaganda brainwashes the people's minds, making them believe in the lies of the regime and enlist to fight its wars. Only educated people resisted: Botard with science and Abu Firas with history. Terror is the upper hand of totalitarianism which distinguishes it from tyranny and despotism. In Rhinoceros, it is infectious, unpredictable, and feared. It changes people's minds and drives them to do evil things. Meanwhile, in Goats, it is state-sponsored, planned, and deliberate. It hushes people, making them a captive audience like Imm Ghassan. Religion is banned and frowned upon in Rhinoceros due to the belief in the supremacy of science and the need for massive production. In Goats, it is pervasive and under the control of sheikhs who pledge loyalty to the totalitarian leader. 
An Arendtian Reading of Eugene Ionesco's Rhinoceros and Liwaa Yazji's Goats

through the Notions of Totalitarianism and The Banality of Evil

Asst. Prof. Hany Ali Mahmoud Abdelfattah

مجلة وادي النيل للاراسات والبحوث الإنسانية والاجتماعية والتربوية (مجلة علمية محكمة)

Thus, it is manipulated by the theocrats who abide by the decrees of the autocrats.

'Work' and 'loyalty' are regarded as sacred duties that people have to carry out no matter what the circumstances are. 'Work' has become modern-day slavery, where people turn to be mere bureaucratic creatures who do evil things to serve their regimes with no regret. 'Loyalty' is viewed as a holy duty especially in times of war. Both 'work' and 'loyalty' reinforce the concepts of conformity and thoughtlessness. Conformity transforms people into mere animals easily led and controlled. Thus, conformity and loyalty create blind spots which make one disregard moral standards and do evil things with no regret. The banality of evil is the state of "thoughtlessness," as Arendt asserts, "It was sheer thoughtlessness--something by no means identical with stupidity--that predisposed him (Eichmann) to become one of the greatest criminals of that period" (Eichmann, 1964, p. 287-8). Thoughtlessness is emphasized in both plays, as Dudard asserts to Berenger "You leave the authorities to act as they think best!" (Rhinoceros, 1960, p. 80) and as when Abu al-Tayyib eulogizes Abu Firas, describing him as having "the luxury of being able to think" (Goats, 2018, p. 131). Berenger and Abu Firas paid a high price for being non-conformists to the end: Berenger is besieged, and Abu Firas assassinated.

Technique plays a major role in both plays: Rhinoceros is a nihilistic absurd drama whereas Goats is a satirical one. The absurd style of Ionesco is symbolic as he feared crackdown by the Fascists, meanwhile, Yazji's is more direct and scathing because she fears no censorship in London. Both used a myriad of techniques to break the illusion and drive the audience not to accept the reality effect. Yazji's Goats, buttressed by the advancement of technology, incorporated new Brechtian techniques such as the screen, the video projections, and documentary materials to solidify the authenticity of the performance. She also employed the gaze of the camera and the 
(ISSN : 2536 - 9555)

crowd to uncover the techniques used by $\mathrm{Ba}$ athists to control the masses and discipline them.

The presence of animals on stage opens a new venue to look at the intersection between totalitarianism, animality, and absurdity. The three constellations overlap in three points: conformity, thoughtlessness, and moral standard. The first turns people into mere cogs in the wheels of the regime, the second emboldens them to do evil things with no regret, and the third transforms them into no more than animals that just breed and eat.

${ }^{1}$ Ionesco coined the term "rhinoceritis" in Rhinoceros, as Dudard says, "So why get upset over a few cases of rhinoceritis" (Rhinoceros, 1960, p.75). Ionesco makes this neologism stand as both destabilization of humanity as well as a metaphor of conformity.

${ }^{2}$ Between 1958-1960 and at the peak of Pan-Arab sentiment after the Suez Canal Crisis in 1956, The Arab Socialist Ba'ath Party succeeded in uniting Egypt and Syria under the name The United Arab Republic but failed soon due to a Syrian coup in 1961. Thereafter, successive military coups d'état destabilized the party until 1971 when Hafiz al-Assad, the former minister of defense, ascended to power through another coup and lasted for thirty years until he died in 2001. During his reign, he became an authoritarian ruler who fully controlled the state and established the Ba'ath Party as the single party of the state.

${ }^{3}$ Hannah Arendt was a German-born American philosopher whose books The Origins of Totalitarianism (1951), The Human Condition (1959), and On Revolution (1963) sparked a heated debate on totalitarianism, freedom, power, and evil. She studied at the University of Marburg under the existentialist philosopher Martin Heidegger whose theories on phenomenology and the Human Reality "Dasien" attracted her. However, Arendt lost her enthusiasm and respect for Heidegger after he became a supporter of the Nazi Party which started to dominate intellectual life. Being a Jewish scholar and doing some research on antisemitism annoyed the Nazis, so she was imprisoned. In 1941, she fled to the USA, settled in New York, and wrote most of her books until 


\section{An Arendtian Reading of Eugene Ionesco's Rhinoceros and Liwaa Yazji's Goats through the Notions of Totalitarianism and The Banality of Evil Asst. Prof. Hany Ali Mahmoud Abdelfattah}

مجلة وادي النيل للار اسات والبحوث الإنسانية والاجتماعية والتربوية (مجلة علمية محكمة)

she died in 1975. The Origins of Totalitarianism (1951) discusses historical circumstances underlying the rise of totalitarianism in Europe in the twentieth century, offering an in-depth analysis of the upsurge in antisemitic sentiment in Germany in part one; the disintegration of the nation-state and the marriage of power and wealth, exemplified in the bourgeois' ascension to power in part two; and finally, the tools which had been used by totalitarianism such as propaganda, terror, and religion in part three.

${ }^{4}$ Violence could easily be escalated into massacres when dictators encounter fierce resistance as what had taken place in Auschwitz by Hitler, Turin by Mussolini, and Katyn by Stalin. Likewise, Syrian President Hafez al-Assad is thought to be behind the Hama massacre in 1982, where he quelled an uprising by Sunni rebels in Hama, killing thousands of people. Totalitarian leaders were not ashamed of these massacres, as Arendt asserts, they "usually start their careers by boasting of their past crimes and carefully outlining their future ones" (Origins, 1973, p.307).

${ }^{5}$ Goats is popular in Egypt because the Egyptian-British Actor Amir El-Masry played the role of Adnan. El-Masry was known in Egypt for his role in the blockbuster Egyptian movie Ramadan Mabrouk Abul-Alamein Hamouda (2008), when he starred opposite the veteran Egyptian comedian Mohamed Henedi, in the "role of a spoiled brat" (Tawfeek, 2017, p. 1)

${ }^{6}$ History stands for the truth, but the truth is sometimes painful. Therefore, the history of defeat still haunts the people even after liberation, as with what happened after the liberation of France on 25 August 1944, when Charles de Gaulle, the French President at this time, declared:

Paris had been freed by itself, freed by its own people with the support of the armies of France, with the cooperation and support of the whole of France, of the France which fights, of the only France, of the true France, of the eternal France. (qtd. In Gabriel, 2003, p.199)

The French President attempted to efface all the memory of the Allied forces' help to free France from the Nazis, glorifying the sacrifices of the French people and completely denying the role of Britain and the US in liberating 
(ISSN : 2536 - 9555)

France. He wanted to efface from memory the harsh reality that Vichy France was a collaborative government that helped the Nazis against the French nation.

${ }^{7}$ Arendt asserted that Nazis had used terror psychologically, as she noted, "Totalitarianism has discovered a means of dominating and terrorizing human beings from within. In this sense it eliminates the distance between the rulers and the ruled and achieves a condition in which power and the will to power, as we understand them, play no role, or at best, a secondary role. (Origins, 1973, p.325)

${ }^{8}$ Hitler exploited martyrdom when he eulogized the sixteen fallen members of the Nazi Party who were killed during the "Beer Hall Putsch" as "martyrs" (Connerton, 1989, p. 42). On 9 November 1923, Hitler led the National Socialist Party members to make a coup against the state, but he failed, shot, and imprisoned. Many of his followers were killed in this attempt. Every year on 9 November, Hitler commemorated the anniversary of their martyrdom by addressing the nation about sacrifice. In Syria, the former Syrian President Hafez Al-Assad did the same; he incorporated/ appended/ "the intraparty coup" (Ziter, 2014, p.118), which brought him to power in 1970, into the calendar of ceremonies.

${ }^{9}$ In the Islamic religion, martyrdom is highly commended, and martyrs are not dead but "alive, with their Sustainer have their sustenance" (Quran 3:169). Since the 8-year war between Iraq and Iran, the conflict between Shiites and Sunnis has been turned into "a cult of martyrdom" (Khoury, 2013, p.15). Syria has a minority ruling Alawite who are Shiites against a majority of Sunnis and that is the reason behind the changing of the concept of martyrdom. Shiites used the martyrdom of Husayn at Karbala, whereas Muslim Sunnis used the "martyrdom of Khansa"s sons in the battle of Qadisiya" (Moosavi, 2015, p.16). 
An Arendtian Reading of Eugene Ionesco's Rhinoceros and Liwaa Yazji's Goats through the Notions of Totalitarianism and The Banality of Evil

Asst. Prof. Hany Ali Mahmoud Abdelfattah

مجلة وادي النيل للار اسات والبحوث الإنسانية والاجتماعية والتربوية (مجلة علمية محكمة)

\section{Works Cited}

Arendt, H., \& Kroh, J. (1964). Eichmann in Jerusalem: a report on the banality of evil. New York: Viking Press.

---, H. (1973). The Origins of Totalitarianism (Vol. 244). Houghton Mifflin Harcourt.

Bahnas, E. E. (2018). "The Influence of Ionesco on Egyptian Dramatists with a Special Reference to Tawfik Al-Hakim, Salah AbdelSabour, and Naguib Sorour." M.A. Alexandria: Alexandria University.

Bailey, C. (2016). Theatre of war: An interview with Syrian playwright Liwaa Yazji. Index on Censorship, 45(1), 60-63.

Bennet, M. Y. (2011). Reassessing the Theatre of the Absurd.

Calinescu, M. (1995). Ionesco and Rhinoceros: Personal and Political Backgrounds. East European Politics and Societies, 9(3), 393432.

Camus, A. (1955). The myth of Sisyphus and other essays, New York (Alfred A. Knopf) 1955.

Coakley, J. F. (1964). The Comic World of Eugene Ionesco: A Study in Dramatic Technique (Doctoral dissertation, Northwestern University).

Connerton, P. (1989). How societies remember. Cambridge University Press.

Deverson, M. (1978). The theme of victim in the works of Eugene Ionesco (Doctoral dissertation).

Dunn, W. S. (1995). The soviet economy and the Red Army, 1930-1945. Greenwood Publishing Group.

ESSLIN, M. (1960). The Theatre of the Absurd. 
(ISSN : 2536 - 9555)

Fambrough, P. (2010). Ionesco's Rhinoceros and the Menippean tradition. Studies in Twentieth and Twenty-First Century Literature, 34(1), 47-62.

Foucault, M. (2007). Discipline and punish: The birth of the prison. Duke University Press.

Freud, S. (1955). Group psychology and the analysis of the ego. In The Standard Edition of the Complete Psychological Works of Sigmund Freud, Volume XVIII (1920-1922): Beyond the Pleasure Principle, Group Psychology and Other Works (pp. 65144).

Friedrich, C. J. (1969). The evolving theory and practice of totalitarian regimes. Totalitarianism in perspective: Three views, 123-164.

Gabriel, B. (2003). The wounds of memory: Mavis Gallant's' Baum, Gabriel (1935-)', national trauma, and postwar French cinema. Essays on Canadian Writing, (80), 189-216.

Graham-Harrison, E. (2017). "A goat for every martyr: the bitterly funny play about the surreal cost of Syria's civil war." https://www.theguardian.com/stage/2017/nov/28/goats-martyrsurreal-cost-syria-civil-war-liwaa-yazji-royal-court Tuesday 28 nov.

Haney, W. S. (2008). Eugene Ionesco's Rhinoceros: Defiance vs. Conformism/Eugene Ionesco's Rhinoceros Adli Eseri: Muhalefet Konformizme Karsi. Interactions, 17(1), 85.

Ionesco, E. (1960). Rhinoceros. Concord Theatricals.

Jahangiri, F. (2016). Marx in Rhinoceros.

Jannarone, K. (2009). Audience, mass, crowd: Theatres of cruelty in interwar Europe. Theatre Journal, 191-211.

Kelly, V. (1977). A Study Of The Theatre Of Eugene Ionesco, University of Toronto (Canada). Ann Arbor. Proquest. Retrieved $<$ https://search.proquest.com/dissertations-theses/study-theatreeugene-ionesco/docview/302870166/se-2?accountid=178282. 
An Arendtian Reading of Eugene Ionesco's Rhinoceros and Liwaa Yazji's Goats through the Notions of Totalitarianism and The Banality of Evil

Asst. Prof. Hany Ali Mahmoud Abdelfattah

مجلة وادي النيل للار اسات والبحوث الإنسانية والاجتماعية والتربوية (مجلة علمية محكمة)

Kemock, K. C. (2007). The Rhinoceros in 2006: A Dramaturgical Analysis of Eugene Ionesco's Rhinoceros (Doctoral dissertation, Miami University).

Khoury, D. R. (2013). Iraq in Wartime: Soldiering, Martyrdom, and Remembrance. Cambridge University Press.

Luciano, D. R. (1977). Application of the elements of a jarryesque sensibility to the plays ofboris vian and eugene ionesco as the critical measure for a contemporary nonsense drama. The University of Iowa.

Moosavi, A. (2015). How to write death: resignifying martyrdom in two novels of the Iran-Iraq War. Alif: Journal of Comparative Poetics, 35(9), 9-31.

Olson, G. (2003). Richard III's Animalistic Criminal Body. Philological Quarterly, 82(3), 301.

Quinney, A. H. (2007). Excess and Identity: The Franco-Romanian Ionesco Combats Rhinoceritis. South Central Review, 24(3), 3652.

Raber, K. (2015). Shakespeare and Animal Studies. Literature Compass, 12(6), 286-298.

Saxonberg, S. (2019). Pre-Modernity, Totalitarianism and the NonBanality of Evil: A Comparison of Germany, Spain, Sweden and France. Springer Nature.

Sirez, A. (2018.). "Goats” By Syrian Playwright Liwaa Yazjiat At The Royal Court" https://thetheatretimes.com/goats-royal-court/.

Pavis, P. (1998). Dictionary of the theatre: Terms, concepts, and analysis. University of Toronto Press.

Spevack, M. (1970). A complete and systematic concordance to the works of Shakespeare. 
(ISSN : 2536 - 9555)

Tawfeek, F. (2017). "Rising Egyptian actor Amir El-Masry is the 'The Arabian Warrior.” Egypt Independent. Dec. 17. 2017. https://egyptindependent.com/rising-egyptian-actor-amir-elmasry-arabian-warrior/. .

Tomass, M. (2016). From the Arab Spring to the Revolt of the Sunna. In The Religious Roots of the Syrian Conflict (pp. 151-185). Palgrave Macmillan, New York.

Weber, M. (1947). The theory of economic and social organization. Trans. AM Henderson and Talcott Parsons. New York: Oxford University Press.

Wulbern, J. H. (1968). BRECHT AND IONESCO: ASPECTS OF ENGAGEMENT.

Yasaka, F. (1979). HUMAN METAMORPHOSIS IN EUGENE IONESCO AND KOBO ABE. Indiana University.

Yazji, L. (2018). Goats. Trans. Katharine Halls. London: NHB Modern Plays.

Youssef, S. (2017). “Arab Dramaturgies on the European Stage: Liwaa Yazji's Goats (Royal Court Theatre, 2017) and Mohammad Al Attar's The Factory (PACT Zollverein, 2018)." Vol 10. https://arabstages.org/2019/07/arab-dramaturgies-on-theeuropean-stage-liwaa-y.

Ziter, E. (2014). Political performance in Syria: From the Six-day war to the Syrian uprising. Springer. 